\title{
СОБЫТИЙНОЕ ПРОСТРАНСТВО КАК ЭЛЕМЕНТ ИВЕНТ-МАРКЕТИНГА
}

\author{
(c) 2018 Войткевич Наталия Ивановна \\ доктор экономических наук, профессор \\ Самарский государственный экономический университет \\ 443090, г. Самара, ул. Советской Армии, д. 141 \\ E-mail: kafedra-ks@yandex.ru \\ (C) 2018 Карпов Иван Алексеевич \\ кандидат экономических наук, доцент \\ Самарский государственный экономический университет \\ 443090, г. Самара, ул. Советской Армии, д. 141 \\ E-mail: karpovivan79@yandex.ru
}

В статье ивент-маркетинг рассматривается как инструмент маркетинговых коммуникаций и как особый вид предпринимательства. Обосновывается содержание маркетинговой деятельности в событийном маркетинге и комплекс маркетинга события, показана роль событийного пространства как составляющей комплекса маркетинга события.

Ключевые слова: ивент-маркетинг, событийный маркетинг, маркетинг события, событийное пространство.

Событийный или ивент - маркетинг как одно из направлений маркетинга появился сравнительно недавно и рассматривается учеными и специалистами преимущественно как инструмент продвижения товаров и услуг компаний, привлекающий внимание целевых аудиторий специально организованными событиями. Так, по мнению Ериной Е.Д. «Событийный маркетинг, который относится к коммуникациям BTL,- это систематическая организация мероприятий как платформы презентации товара (услуги) для того, чтобы с помощью эмоционального воздействия активизировать внимание целевой аудитории к компании, её товару (бренду) или услуге» [1]. Жилените И.Р. и Скоробогатых И.И. [2] разделяют эту позицию и также относят событийный маркетинг к BTL коммуникациям. Козлова О.А. [3] считает, что событийный маркетинг использует различные инструменты рекламы и $\mathrm{PR}$ и часто для его реализации требуются знания и навыки из смежных областей: искусства, науки, психологии, общественной деятельности. По мнению М.М. Корсаковой [4] ивент-мероприятие является непрямой рекламой, а ивент - сравнительно недорогим средством продвижения.

Вместе с тем существует близкая нам точка зрения, согласно которой событийный маркетинг рассматривается двояко: как инструмент маркетинговых коммуникаций и как особый вид предпринимательства. Например, Манихин А.А. утверждает, что событийный маркетинг является видом интегрированных маркетинговых коммуникаций, представляющий собой комплекс мероприятий, направленных на продвижение бренда в маркетинговой среде посредством организации специальных событий, и сферой услуг по организации специальных мероприятий» [5].

Частично поддерживая эту позицию как наиболее полно характеризующую современный ивент- маркетинг, считаем, что событийный маркетинг является специфичным видом маркетинга, философией предпринимателей, занимающихся организацией ивент- мероприятий, а также содержанием их практической деятельности на рынке ивент-услуг, связанной с организацией и проведением событий, формированием определенного событийного пространства, коммуникациями по продвижению события, продажами своих услуг, стимулированием их сбыта и т.д. Однако рассматривать ивент- маркетинг только как вид маркетинговых коммуникаций, значит существенно недооценивать его значение. Представляется целесообразным для раскрытия содержания этой стороны ивент- маркетинга использовать термин маркетинг события, предложенный А.В. Малыгиным, и нашедшим поддержку у А.В. Панкрухина [6], поскольку в этом случае речь идет не только о маркетинго- 
вых коммуникациях.

В маркетинге событий товаром является событие, организованное мероприятие, в событийном маркетинге товаром следует считать услугу ивент компаний по организации события с целью продвижения какой-либо идеи, компании, территории, товара, личности, с целью привлечения туристов или удовлетворения потребностей других целевых групп. Руководствуясь принципами маркетинга и используя его инструменты в своей деятельности, компании, работающие на рынке ивент-услуг, применяют событийный маркетинг, товаром в котором являются их услуги. Однако при организации конкретного события эти сервисные компании применяют маркетинг события, где товаром является это событие.

Термин «событие» относится к совокупности явлений, разного характера и значимости, типология событий может осуществляться по ряду признаков. Так, наиболее полную, по-нашему мнению, группировку спланированных событийных туристских мероприятий в зависимости от их целей и программы дала А.Ю. Александрова:

- политические и государственные - саммиты, визиты VIP персон, торжества в королевских домах мира и т.д.;

- культурные - фестивали, карнавалы, концерты, памятные церемонии, церемонии награждения и т.д.;

- деловые - переговоры, совещания, выставки-ярмарки и т.д.;

- научные и образовательные - форумы, открытые лекции, мастер-классы и т.д.;

- досугово-развлекательные - игровые соревнования и т.д.;

- спортивные - спортивные соревнования среди профессионалов и любителей по видам спорта [7].

При этом надо отметить, что не каждое событие является туристским, многие организованные события носят локальный характер и ориентированы только на местных жителей. Значительная часть ивент мероприятий носит узкокорпоративный, дружественный или семейный характер. К туристским событиям относятся те события, что привлекают туристов, являются мотивом поездки и часто организуются в целях формирования туристского потока в ту или иную дестинацию.

Использование понятия маркетинг события позволяет не только говорить о событии как о товаре, но и детально изучать функциональные инструменты комплекса маркетинга события. В этой связи предлагается рассмотреть понятие событийное пространство как элемента комплекса маркетинга в маркетинге туристских событий, ввиду актуальности развития событийного туризма в стране, его значимости для экономики страны и ее отдельных территорий.

Как известно, основой развития событийного туризма является наличие интересных событий, привлекающих большое количество туристов. Однако необходимым условием успешного проведения того или иного события является наличие соответствующего событийного туристского пространство, которое должно обеспечить не только проведение события, ради которого приезжают туристы, но и их размещение, питание, безопасность, удовлетворить информационно-технические, культурно - познавательные потребности туристов, другие формы проведения досуга.

С позиций маркетинга событийное пространство - это сложная составляющая комплекса маркетинга события, являющаяся частью товара, поскольку любое событие имеет определенную инфраструктуру, без которой оно просто не может состояться. Так, например, для проведения спортивного соревнования нужны спортивные сооружения, фестивалей - соответствующее оформление и площадки. Кроме того событийное пространство - элемент материального окружения в комплексе 7P, физического подтверждения качества, возможно, престижности той услуги, которую получает турист, участвуя в событии. И, безусловно, изображения событийного пространства или отдельных его элементов, их вид, информация в СМИ об этапах формирования этого пространства способствуют продвижению события, пробуждает интерес к нему.

Если посмотреть, что включает в себя туристское событийное пространство, то определяющим элементом любого туристского событийного пространства, без сомнения, является событие из области спорта, науки, культуры, бизнеса, светской и политической жизни, а также уникальные явления природы, привлекающие внимание туристов. Кроме того, событийное пространство включает различные виды инфраструктуры - это специализированная инфраструктура самого туристского события, 
туристская, транспортная, информационная, культурно - развлекательная, спортивная, торговая, финансовая инфраструктуры, а также инфраструктура гостеприимства - предприятий общественного питания и средств размещения.

Следует отметить, что событийное туристское пространство это на только пространство в физическом смысле с соответствующими материальными объектами, необходимой инфраструктурой, но и определенная атмосфера, связанная с событием, подчеркивающая его значимость. Создает эту атмосферу праздника не только ожидание и наступление основного события, в связи с которым формируется определенное пространство, но и менее значимые по сравнению с основным события спортивного, культурного характера. Именно поэтому все значительные спортивные мега события Олимпиады, Универсиады, чемпионаты мира по футболу и т.д. сопровождаются культурными мероприятиями различного содержания и уровня, направленными на создание праздничной атмосферы и, безусловно, на удовлетворение потребностей различных целевых групп. Это позволяет спортивные и культурные мероприятия, приуроченные, например, к проведению такого мега события, как ЧМ-2018 по футболу относить к событийному пространству этого мега события.

Событийное пространство характеризуется многообразием событий, участников, элементов инфраструктуры и наличием тесных взаимосвязей между объектами, что позволяет сформировать сложный туристский продукт, удовлетворяющий потребности не только различных групп туристов, но и отдельных индивидуумов. Действительно, попадая в событийное туристское пространство, турист получает особую потребительскую ценность, состоящую из ценности основного туристского события и дополнительную ценность сопутствующих основному событию мероприятий, а также ценность особой атмосферы события, неформальных контактов с другими туристами и местными жителями. В результате основное событие, ради проведения которого сформировано событийное пространство, становится не просто товаром в комплексе инструментов - маркетинга события, а товаром с подкреплением, имеющим более высокую ценность для потребителей.

Так, например, событийное пространство прошедшего Чемпионата мира по футболу2018 в России обеспечивало туристам знакомство с достопримечательностями, культурой, традициями, историей городов, где проходили футбольные матчи, возможность отдохнуть, встретиться с другими болельщиками и местными жителями. В городах, принимавших участников и гостей чемпионата, были созданы фан-зоны для совместного времяпрепровождения болельщиков и просмотра матчей, транслируемых в прямом эфире на больших экранах. Кроме того, в фан-зонах были организованы различные увеселительные мероприятия, в перерывах между матчами проводились концерты.

Учитывая важность событийного пространства для успеха события, для формирования имиджа товара, компании или территории к нему предъявляется ряд требований. К ним относятся:

- удовлетворение потребностей всех целевых групп, для которых оно формируется;

- комфортность и безопасность;

- создание позитивной, дружественной атмосферы;

- «информационная прозрачность», поддерживающая интерес к событию и территории;

- насыщение пространства дополнительными событиями культурного, развлекательного и познавательного характера;

- прагматичность при принятии решений о создании и модернизации объектов инфраструктуры с учетом их дальнейшего использования для нужд территории.

Оригинальное красочное оформление, удобство, безопасность, огромное количество развлекательных мероприятий, доброжелательное отношение населения и атмосфера праздника это характеристики событийного пространства Москвы в период проведения ЧМ-2018, оставившего яркие впечатления у туристов, является залогом развития туризма и позитивного отношения к стране и ее людям.

Таким образом, ивент-маркетинг как одно из современных направлений маркетинга следует рассматривать, во-первых, как вид предпринимательской деятельности ивент организаций на рынке услуг, и в этом случае речь идет о событийном маркетинге, а во-вторых, как маркетинг событий, использующий инструменты маркетинга для продвижения какого-либо организованного события. Необходимой составляющей комплекса маркетинга события является событийное пространство, которое имеет особо 
важное значение при организации туристских событий.

\section{Библиографический список}

1. Ерина Е.Д. Фестиваль как инструмент событийного маркетинга // Event-маркетинг. 2013. № 2 (06). С. 116

2. Жилените И.Р., Скоробогатых И.И. Эффективность событийного маркетинга (на примере организации события: приёма легендарного маркетингового гуру профессора Филипа Котлера в РЭУ имени Г.В. Плеханова)//Инициативы XXI века. 2014. № 4. С. 45-49.

3. Козлова О.А. Событийный маркетинг как инструмент повышения лояльности потребителей. Концепт. Спецвыпуск № 4. 2016. С. 10-16.

4. Корсакова М.М. Ивент-агентство «Альфа» на грани краха: Правила построения эффективной сервисной компании. Альпина Диджитал, 2012.

5. Манихин А.А. Ткань событий. Место event-маркетинга в комплексе маркетинговых коммуникаций // Креативная экономика. 2010. № 4 (40). С. 135-142.

6. Панкрухин А.П. Маркетинг событий в России: новый «мейнстрим»?//Практический маркетинг. 2012. № 3. C. 6-14.

7. Александрова А.Ю. Интеграция событийных мероприятий в продвижении туристских дестинаций на принципах ко-брендинга// Вестник Московского университета. Серия 6. Экономика. 2015. № 6. С. 135-162.

Поступила в редакцию 14.08.2018 